CHAPTER FOUR

\title{
THE MORALITY OF HYPOCRISY: GNAPHEUS'S LATIN PLAY HYPOCRISIS AND THE LUTHERAN REFORMATION
}

\author{
Verena Demoed
}

\section{INTRODUCTION}

In drama, moral judgment is not uttered through words alone; it can also be expressed through non-verbal and seemingly subsidiary things such as props, costumes and stage action. ${ }^{1}$ This paper will attempt to clarify how Gnapheus used his Latin plays, especially his Hypocrisis ('Hypocrisy', published in 1544 and 1564), in debates on religious matters. Gulielmus Gnapheus Hagiensis, or Willem de Volder (Fuller), or Van de Voldersgraft, of The Hague (1493-1568) is an example of a committed writer. He held outspoken views on the Protestant reformations, which he expounded in pamphlets and plays. Because of his commitment, his oeuvre is pre-eminently suitable as material in an investigation of the role literature played within public debate, and the effect it may have had on public opinion. Hypocrisis is his most outspoken play. It was written and produced in East Prussia, where Lutheranism was proclaimed as a state religion. This enabled the author (he may even have felt obliged) to expound his reformational ideas in a more direct, explicit and uncompromising manner than he would have done in the Low Countries and West Prussia, where he lived before the 1540s, and which at that time still remained officially Catholic. Though even here, in Lutheran East Prussia, Gnapheus came into conflict with the ecclesiastical authorities: he was indicted for heresy by the Lutheran theologian Staphylus.

1 This paper was written within the scope of the Vidi-project Latin and Vernacular Cultures: Theatre and Public Opinion in the Netherlands (ca. 1510-1625), funded by the Dutch Organisation for Scientific Research (NWO). With thanks to J. Trapman for his comments on an earlier draft of this paper, and to A.G. Weiler for his information. All translations of Latin quotations are mine, unless stated otherwise. 
In order to decide for or against the rhetorical or even propagandistic function of drama, a contextual and intertextual approach has been chosen. I will first sketch the social context in which the play was written, staged, printed and read: that of the Latin school and University of Königsberg, where the play was performed, the court of the Duke of East Prussia, the printers and publishers of the play in Basel and Wittenberg, and Gnapheus's Lutheran critics. Furthermore, Hypocrisis will be positioned within a broader perspective: the discourse of the Reformation in general, and that of the Lutheran Reformation in particular. This paper will explain how the context of Protestant criticism affected Gnapheus's dramatic works and impinged upon other genres such as that of the vernacular morality play and on other means of communication, such as visual ones, for instance tableaux vivants, or printed ones, such as popular woodcuts. It will be argued that in his Latin plays Gnapheus makes use of the generic conventions and the same well-known motifs and representational modes that were also used by vernacular playwrights and pamphleteers. The specific sources Gnapheus used when writing his plays can no longer be traced, so this analysis will make use of representative examples, or sample texts with themes common at this time. These 'texts' are: Gnapheus's other works, Luther's writings, a Dutch table or dinner play, ${ }^{2}$ and pamphlets referred to in Scribner's work on popular propaganda during the Lutheran Reformation in Germany. ${ }^{3}$ The popular woodcuts Scribner discusses were thought to be pre-eminently suited to reach and educate the young, the illiterate and the semiliterate: 'children and simple folk, who are more easily moved by pictures and images to recall divine history than through mere words or doctrines'. ${ }^{4}$ Humanist playwrights such as Gnapheus used their dramatic works first and foremost to the same ends: to teach their pupils at the Latin schools, just as the Dutch rhetoricians tried to educate their audiences. ${ }^{5}$ At the same time, they sought to appeal, by means of a printed publication of the play, to a humanist readership. And even though both their target audiencestheir pupils and the respublica literaria-were familiar with classical antiquity, I want to show, by using a contextual approach, that Latin

\footnotetext{
${ }^{2}$ On this particular genre, see Pikhaus, Het tafelspel bij de rederijkers.

${ }^{3}$ Scribner, For the Sake of Simple Folk; idem, Popular Culture and Popular Movements in Reformation Germany.

${ }^{4}$ Scribner, For the Sake of Simple Folk, p. xi.

${ }_{5}^{5}$ Waite, Reformers on Stage, pp. 26-27, 203.
} 
drama was not just elitist ivory-tower classical humanism, and that 'classical and humanist models need not be remote from popular cultural forms, but that the one was often grafted onto the other'. ${ }^{6}$

\section{The Protestant Playwright and Pamphleteer Gnapheus}

Gnapheus was-and still is-primarily famous for his first Latin comedy Acolastus. He wrote and probably staged the play while he was a teacher and headmaster of the Latin school in his hometown of The Hague from 1522 to 1528. It was published in Antwerp in 1529, after he had fled his motherland (Holland) on religious grounds. The play was a great success: it was frequently reprinted, staged, translated into the vernacular, and adapted for other Latin dramas on the same subject. ${ }^{7}$

In the Low Countries, Gnapheus was a publicly known evangelical during the tempestuous period of the early Reformation. ${ }^{8} \mathrm{He}$ was imprisoned twice, in 1523 and 1525, the second time for having written a consolatory letter to a widow whose son had left the monastery, in which he ridiculed monastic life. ${ }^{9}$ During his three-month prison sentence-in a monastery-he states that he wrote the famous pamphlet Een troost ende spiegel der siecken ende derghenen die in lijden zijn [...] (A Comfort and Mirror for the Sick and Suffering, published in 1531). In this pamphlet he continues to attack the Catholic clergy, and to expound evangelical ideas..$^{10}$ Eventually, in 1528 , he was outlawed and fled the Low Countries for Elbing (now Elbląg), in West Prussia, in the Roman Catholic Kingdom of Poland. In Elbing Gnapheus wrote and staged the plays Triumphus Eloquentiae ('Triumph of Eloquence', published in 1541), and Morosophus ('The Foolish Sage', 1541). Both

${ }^{6}$ Scribner, For the Sake of Simple Folk, p. 64.

7 The play was translated into English by Palsgrave in 1540. See The Comedy of Acolastus. Translated [...] by John Palsgrave, ed. Carver. Some Latin adaptations are Papeus's Samarites (Samarites. Comoedia de Samaritano Euangelico, Antwerp: Montanus, 1539), and Stummelius's Studentes (written in 1545, published in 1548), see Lachmann, Die 'Studentes' des Christophorus Stymmelius und ihre Bühne.

${ }^{8}$ Spruyt, Cornelius Henrici Hoen, pp. 59-74; Roodhuyzen, Het leven van Guilhelmus Gnapheus, pp. 15-25, 81-84.

9 The letter is lost. Gnapheus mentions it in the dedication of his Tobias ende Lazarus ('Tobias and Lazarus', published in 1557), a revised edition of an earlier pamphlet, Een troost ende spiegel [...]. Ibid.

${ }_{10}$ Bibliotheca Reformatoria Neerlandica, 1, pp. 151-249. 
plays are critical of mediaeval, Roman Catholic scholasticism, and advocate either a return to the simplicity of the early Christian Church (Morosophus), or to the humanities and classical studies (Triumphus Eloquentiae). ${ }^{11} \mathrm{He}$ also published imitations of classical and biblical sources written by his pupils (Foetura, 1541), and an encomium on Elbing for its support of the bonae literae and the establishment of the Latin school (Paraenesis, 1539). ${ }^{12}$ In short, in Elbing Gnapheus concentrated wholly on the study of the classics. Gnapheus was banned from the town in 1541, this time not only because of Lutheran, but also for Sacramentarian and Anabaptist views, ${ }^{13}$ even though he himself states that envy and his ideas about the marriage of priests were the cause. ${ }^{14}$ He left Elbing with wife and family, and settled for Königsberg (Polish: Królewiec, now Kaliningrad) in Lutheran East Prussia. After his arrival in Königsberg in 1541, Gnapheus became one of Duke Albert's counsellors for educational matters. ${ }^{15}$ In 1542 he began to teach at the Latin school of Königsberg. In his capacity as a teacher he wrote his last Latin play Hypocrisis, which he staged with his pupils in $1543 .{ }^{16}$

${ }_{11}$ Bibliotheca Reformatoria Neerlandica, 1, p. 140.

${ }_{12}$ Biografisch Lexicon voor de Geschiedenis van het Nederlandse Protestantisme, 4, pp. 142-44.

${ }_{13}$ De Vocht, John Dantiscus and his Netherlandish friends, p. 325; Rädle, 'Zum dramatischen Schaffen'. Sacramentarianism rejected the Roman Catholic and Lutheran doctrines of transubstantiation and consubstantiation respectively, that is, of the physical or corporeal presence of the body and blood of Christ in the bread and wine during the celebration of the Eucharist. Anabaptists are best known for their rejection of infant baptism; instead they advocated adult baptism, or baptism of the faithful. Although they were mostly pacifists and kept to themselves, their adversaries (including Luther) regarded them as violent revolutionaries. The Peasants' Revolt (1524-1525) and their bloody occupation of Münster (1534-1535) seemed to confirm these suspicions. See Hillerbrand, The Oxford Encyclopedia of the Reformation, 1, pp. 31-35; 3, pp. 462-63; Lindberg, The European Reformations, pp. 185, 199-225; and Williams, The Radical Reformation, pp. 95-108, 175-96, 528-35, 539-47, 607-17.

${ }^{14}$ Gnapheus, Antilogia, fol. A8v: ' [...] quid me, quaeso, inde pepulit, et dolentibus adeo Musis eiecit, nisi et aemulorum quorundam invidia, et ingenua aditi praeter pontificias sanctiones in domino coniugii confessio, apud Dantiscum Episcopum libere data?' ('what, I ask you, chased me away from there, and threw me out of my school, if not the jealousy of my rivals, and a frank confession voluntarily made to Bishop Dantiscus [of Warmia, VD] of a marriage in the Lord contracted in defiance of papal law').

${ }_{15}$ Hubatsch, Geschichte der Evangelischen Kirche, p. 76; Biografisch Lexicon voor de Geschiedenis van het Nederlandse Protestantisme, 4, p. 143.

${ }^{16}$ Gnapheus, Hypocrisis (1564), fol. A8 : 'Acta primo omnium Regiomonte Borussiae, in Academia recens ibi tum instituta, ludis Minervalibus, in illustrissimi Borussorum Principis praesentia, D[omino] Georgio Sabino Rectoratum gerente, Gregis vero Histrici ductore Gul[ielmo] Fullonio Gnapheo, eiusdem fabulae autore. Egere 
In 1544 the Latin school was integrated into the newly established University of Königsberg, ${ }^{17}$ and Gnapheus then became the rector of the Latin school. He also gave lectures on theology at the university, because at the time there was no qualified professor available. ${ }^{18}$

In Königsberg Gnapheus seems to have felt safe enough to finally criticize the Roman Catholic Church directly, quite explicitly, and no longer anonymously (as he had done in the aforementioned pamphlet Een troost ende spiegel), for Hypocrisis seems to be his final reckoning with Catholicism. ${ }^{19}$ His overt break with the Church, however, did not immediately make Gnapheus a devout Lutheran. At least, this was the judgement of the Lutheran ecclesiastical authorities in Königsberg, as will be shown in the next section. After the heresy trial, the ensuing excommunication from the Lutheran Church and banishment from Prussia, Gnapheus found refuge in Emden in East Frisia, at the court of Countess Anna of Oldenburg. Emden had become a safe haven for many Dutch refugees, and a Dutch church in exile was established. ${ }^{20}$ Here Protestant (mainly Calvinist) literature was printed to be distributed in the Low Countries, ${ }^{21}$ and so were some of Gnapheus's pamphlets. In Emden he published Tobias ende Lazarus, a revised version of his Een troost ende spiegel, ${ }^{22}$ the martyrology of Johannes Pistorius Woerdenatis, or Jan de Bakker (Baker) from the Dutch town of

autem Paulus Ekelus Silesita, Christophorus Pruys Regiomontanus. Israel Monetarius Mariaeburgus. Ioannes Rosenbergus Dantiscanus, et Theodoricus Montfortius, actores primarii. D[omino] Bartholomaeo Reichou, et Laurentio Meuues veteris oppidi Co[n] s[ulibu]s. Salutis nostrae anno 1543' ('Performed for the first time of all [performances of Latin plays, VD] in Königsberg in Prussia, at the newly established university, during the ludi Minervales, in the presence of the illustrious Prince of Prussia, when Georgius Sabinus was headmaster, but Gulielmus Fullonius Gnapheus, the author of this play, directed the theatre troupe. Paulus Ekelus from Silesia, Christophorus Pruys from Königsberg, Israel Monetarius from Marienburg, Ioannes Rosenbergus from Danzig and Theodoricus Montfortius played the lead. Mr. Bartholomaeus Reichou en Laurentius Meves were consul of the old city. In the year 1543').

17 Von Selle, Geschichte der Albertus-Universität, p. 16; Biografisch Lexicon voor de Geschiedenis van het Nederlandse Protestantisme, 4, p. 143.

${ }_{18}$ Von Selle, Geschichte der Albertus-Universität, pp. 22-23; Mennecke-Haustein, Conversio ad ecclesiam, p. 65; Rädle, 'Zum dramatischen Schaffen', p. 232.

${ }^{19}$ Rädle, 'Theatralische Formen', pp. 280-88.

${ }^{20}$ Hillerbrand, The Oxford Encyclopedia of the Reformation, 2, pp. 39-40; Williams, The Radical Reformation, p. 540.

${ }^{21}$ Hillerbrand, The Oxford Encyclopedia of the Reformation, 2, pp. 39-40; Porteman and Smits-Veldt, Een nieuw vaderland voor de muzen, p. 57.

${ }^{22}$ Ibid. 
Woerden, first in Latin, later in Dutch, ${ }^{23}$ and a Zwinglian theological treatise: a Dutch translation of Bullinger's Summa Christlicher Religion. ${ }^{24}$ Some of his work was not specifically intended for a Dutch audience, such as his revised edition of his famous play Acolastus, the second edition of Hypocrisis, and his Antilogia, a moving (though, of course, subjective and biased) autobiographical report with a noticeably indignant tone about his fortunes in Königsberg. ${ }^{25}$ The latter two, in which Gnapheus also refutes some of the accusations made against him during the heresy trial, targeted the Lutheran elite, with the intent of rehabilitating himself after his excommunication.

\section{HYPOCRISIS AND THE HERESY TRIAL AGAINST ITS AUTHOR}

One of his colleagues in Königsberg, the theologian Fridericus Staphylus (Friedrich Stapellage, 1512-1564), who succeeded Gnapheus as lecturer in divinity at the city's university, charged Gnapheus with heresy in $1547 .{ }^{26}$ Staphylus came to Königsberg in 1546. He never made friends with Gnapheus, and personal conflicts, rather than a professional dispute, seem to have led to the trial. ${ }^{27}$ Gnapheus had to

23 Gnapheus, Johannis Pistorii a Worden, ob Evangelicae doctrinae assertionem, apud Hollandos primo omnium exusti, Vita ('The Life of Johannes Pistorius, a native of Woerden, the first to be burned in Holland because of his evangelical confession of faith', 1546); Een suverlicke ende seer schoone disputacie, welcke gheschiet is in den Haghe in Holland, tusschen die kettermeesters ende eenen Christelijcken priester ghenaemt Jan van Woorden, aldaer ghevanghen ende oock verbrant [...] ('A true and very beautiful disputation, which took place in The Hague in Holland between the inquisitors and a Christian priest named Jan, native of Woerden, who was imprisoned there and also burned', ca. 1552-1554). The Latin version was translated into Dutch and inserted in the famous Calvinist martyrology of Van Haemstede: De gheschiedenisse ende den doodt der vromen Martelaren ('The history and martyrdom of the pious Martyrs', first published in 1559).

24 Heijting, Catechismi en confessies, p. 360.

${ }_{25}$ Gnapheus, Adversus temerariam, ne dicam impiam excommunicationis censuram [...] a quibusdam Academiae Regimontanae apud Prutenos nuper institutae professoribus et concionatoribus ex mera invidia et malignandi libidine in ipsum latam, extemporalis quaedam Antilogia ("An extempore answer to the ill-considered, not to say impious, excommunication imposed on him [Gnapheus, VD] by some of the professors and instigators of the newly established University of Königsberg in Prussia out of sheer jealousy and a desire for scandal', 1551).

${ }^{26}$ Mennecke-Haustein, Conversio ad ecclesiam, pp. 65-74; Rädle, Zum dramatischen Schaffen, pp. 232-41.

27 For instance, Gnapheus criticized some of his colleagues, among them the main prosecutor Staphylus, for giving expensive, private lessons, but neglecting their public lectures. Gnapheus, Antilogia, fol. B2r . Also, Gnapheus's theses seem to have been 
defend himself extempore against Staphylus's complaints before representatives of the Lutheran Church and the university, chaired by Johannes Briesmann, the Lutheran (or, from a Catholic point of view, apostate) bishop of Samland, a secularized diocese in East Prussia. ${ }^{28}$ The evidence consisted of the theses that Gnapheus advanced when he took his doctor's degree, testimonies of witnesses, a pamphlet allegedly written by Gnapheus, and two of Gnapheus's plays: Morosophus and Hypocrisis. ${ }^{29}$

Staphylus probably did not see the plays performed, ${ }^{30}$ but he scrutinized the printed copies to collect evidence proving the author's heresy. Hypocrisis appeared in print twice. It was first published in 1544 in Basel, where Catholicism was overthrown and a Reformed Church was

written against Staphylus's teachings. Staphylus, Scriptum contra Apologiam Gnaphei, fol. $5^{\text {v: }}$ 'Sumo itaque ex isto libro nihil aliud, quam quae cum publicis erroribus concinn[e] congruere animadverto, praesertim in thematibus mihi oppositis, quos renovavit errores' ('I extract from that booklet nothing more than what I think fits [his] publicly known errors perfectly, especially those he maintained in the theses he wrote against me'). And fol. $6^{\mathrm{v}}$ : 'In non excusis thematibus proponit agnoscendi Dei modum meis disputationibus plane contrarium [...]' ('In his unpublished theses he proposes a way of knowing God explicitly contradicting my lectures'). MenneckeHaustein furthermore states that Gnapheus's collegues did not want him to give lectures on theology, being only a baccalaureus. Mennecke-Haustein, Conversio ad ecclesiam, p. 65.

${ }^{28}$ Mennecke-Haustein, Conversio ad ecclesiam, pp. 67-68; Gnapheus, Antilogia, fol. $\mathrm{C} 4^{\mathrm{v}}-\mathrm{D} 2^{\mathrm{v}}$.

${ }^{29}$ The theses and objections to them are included in Gnapheus's Antilogia (fol. B6r ${ }^{\text {- }}$ $\mathrm{C1}^{\mathrm{v}}, \mathrm{D}^{\mathrm{v}}-\mathrm{F} 4^{\mathrm{r}}$ ) and Staphylus's treatises Confrontation of Articuli Veri with Articuli falsi Gnaphei (this is a written copy of the accusations Staphylus made during the session Gnapheus asked for in order to respond to them more coherently) and Scriptum contra Apologiam Gnaphei (a response to Gnapheus's refutation of the aforementioned Confrontation of Articuli Veri with Articuli falsi Gnaphei; this 'apology' of Gnapheus has not (yet) come down to us). Neither Gnapheus nor Staphylus recorded the testimonies; Gnapheus mentions them and states they were quickly dismissed as irrelevant $\left(\right.$ fol. C $5^{r}$ ). Concerning the pamphlet, the Lutheran bishop Paul Speratus wrote a treatise against the Dutch Anabaptist refugees in Prussia, entitled Ad Batavos vagantes (To the wandering Batavians), vagantes having a double meaning of wandering, and erring, the latter refering to their unorthodox religious views. Gnapheus is accused of having written an apology in answer to this treatise in defence of the Dutch refugees: Apologetica responsio Hollandorum (Apologetical Reply of the Dutch, 1536). See also Gnapheus, Antilogia, fol. C6 ${ }^{\mathrm{v}}-\mathrm{C}^{\mathrm{r}}$; Staphylus, Scriptum contra Apologiam Gnaphei, fol. $\left.3^{\mathrm{r}}, 5^{\mathrm{r}-\mathrm{v}}\right)$; Hubatsch, Geschichte der Evangelische Kirche, p. 76; and Williams, The Radical Reformation, p. 615.

${ }^{30}$ Morosophus was staged solely in Elbing (before 22 January 1540). This is the date of Gnapheus's letter to Duke Albert in which he dedicated Morosophus to him. See Tschackert, Urkundenbuch, 1233. The date of the (official) dedicatory epistle is Christmas 1541-see Gnapheus, Morosophus, fol. A2 ${ }^{\mathrm{v}}$. Hypocrisis was performed in Königsberg in 1543, three years before Staphylus's arrival. 
established in 1529. This is the text Gnapheus's prosecutor used. Going into detail, this version of Hypocrisis indeed contains passages that do not fully correspond to Lutheran doctrines, and thus enabled the prosecutor to have Gnapheus condemned. ${ }^{31}$ Staphylus used the plays as circumstantial evidence: to show that the heretic views expressed in the theses were not a slip of the tongue, but that Gnapheus expounded these unorthodox ideas everywhere, even in seemingly innocent Latin 'school plays'. ${ }^{32}$

Staphylus accused Gnapheus of purposely passing over certain important Lutheran doctrines concerning the Law of Righteousness and the forgiveness of sins by grace, ${ }^{33}$ and of asserting that man can be freed from sin, whereas Lutherans ought to believe that even the saints are sinful. ${ }^{34}$ Last but not least, Gnapheus was accused of confus-

${ }^{31}$ To give an example of the non-Lutheran content of Hypocrisis, Rädle solely quotes Gnapheus, Hypocrisis (1544), fol. 68 (V.1): 'Simulatis qui nunc magnam sanctimoniam, / Fidemque inanem iactatis sine operibus' ('who now feign a great sanctimony, and brag about their faith, vain without works'). Rädle, Theatralische Formen, p. 285. However, Staphylus does not object to these verses in his accusations. The passage may not have been useful to him, because it can be authorized by James 2, 20: 'vis autem scire o homo inanis quoniam fides sine operibus otiosa est' ('But wilt thou know, $\mathrm{O}$ vain man, that faith without works is useless?'). Translation $K J V$ and NKJV. All the same, Gnapheus deleted these two verses (which seem to emphasize the importance of works, and therefore to oppose Lutheran dogmatics) when preparing the script for reprint in Wittenberg in 1564.

${ }^{32}$ For instance Staphylus, Scriptum contra Apologiam Gnaphei, fol. $7^{\mathrm{v}}-8^{\mathrm{r}}$ : 'Neque ego ideo ex Morosopho et Hypocrisi aliquot locos produxi, ut eius oppugnarem lucubrationes, sed quia haud pauca video esse, quae cum his thematibus conveniunt' ('I am not producing evidence from his Morosophus or Hypocrisis because I bear his lucubrations a grudge, but because I observe many things that correspond to these theses').

${ }^{33}$ Staphylus, Confrontation of Articuli Veri with Articuli falsi Gnaphei, fol. $2^{\text {r: }}$ : 'Gnapheus describens penitentiam in Hÿpocrisi [...] studiose praetermittit doctrinam legis damnatricis, quae patefatiat peccatum, iram Dei adversus peccatum, et condemnationem mortis aeternae propter peccatum' ('When Gnapheus is describing repentance in Hypocrisis he purposely keeps back the doctrine of the damning Law, that reveals sin, God's ire concerning sin, and the condemnation to eternal death because of sin'); and fol. 2. 'Gnapheus [...] describet [...] in Hipocrisi quomodo regenerentur Psÿche, tum nullo verbo gratuite remissionis peccatorum promissae propter Christum non meminit' ('When Gnapheus describes in his Hypocrisis how Psyche regenerates, he does not breathe a word of the forgiveness of sins by grace through Christ').

${ }^{34}$ Staphylus, Confrontation of Articuli Veri with Articuli falsi Gnaphei, fol. $3^{\text {r: }}$ 'Gnapheus fingit in sua Hipocrisi, hominem renatum, ita exui et repurgari ab omnibus pravis affectibus, ut verissima ardeat dilectione, tum Dei tum proximi' ('Gnapheus pretends in his Hypocrisis that a regenerated man has so laid down and is so cleansed of base emotions, he or she is burning for true love for God and his or her neighbour'); and fol. $2^{\mathrm{v}}$ : 'Tollunt aut certe valde extenuant Pelagiani peccatum Originale cum fingunt hominem postquam sit renatus ab omnibus pravis affectibus repurgari, 
ing the Law and the Gospel-the Law, i.e. the Old Testament with its righteous God, and the Gospel, i.e. the New Testament with its merciful, gracious God-and thus Catholicism and Lutheranism, a serious offence indeed: Staphylus assures us that 'one cannot say a more pernicious thing than this confusion'.$^{35}$ According to Parente, Catholic plays emphasize the value of good works and a strict observance of the Law in order to achieve salvation. ${ }^{36}$ Staphylus accuses Gnapheus of the same, which comes as a mild surprise, because Gnapheus seems to have written Hypocrisis for precisely the opposite reason: to show that the Roman Catholic notion of good works, such as pilgrimages, fasting, indulgences or alms-giving, is not the right way to salvation.

To state his case Staphylus quotes from an epigraph preceding the play which admonishes the reader that he can only attain salvation if he manages to repress his emotions and the fire of savage Cupid. ${ }^{37}$ Staphylus feels that Gnapheus should have ascribed salvation to faith, and not to abstinence (the repression of emotions and lust). ${ }^{38}$

cum Paulus et universa scriptura doceat in hac vita ita non tolli peccatum quin radix peccati maneat eciam in Sanctis' ('Pelagianists remove, or at least dilute, Original sin, when they pretend that after his or her regeneration he or she is cleansed of base emotions, whereas St. Paul and the Scriptures as a whole teach that sin cannot be removed during this life and that the source of sin remains even in Saints').

${ }^{35}$ Staphylus, Confrontation of Articuli Veri with Articuli falsi Gnaphei, fol. 2v: 'Legem atque Evangelium confundere plus est quam Pelagianum, cum enim lex mortis, Evangelium vero author sit vitae, nihil potest hac confusione dici pernitiosius' ('It is even worse than Pelagianism to confuse the Law and the Gospel, for the Law engenders death, the Gospel on the other hand life. Therefore one cannot say a more pernicious thing than this confusion'). See also Scriptum contra Apologiam Gnaphei, fol. $8^{\mathrm{v}}-9^{\mathrm{v}}$.

${ }^{36}$ On the difference between Catholic and Protestant plays and their respective ideas on the effectiveness of good works to attain salvation, see Parente, Religious Drama and the Humanist Tradition, p. 78-86.

${ }^{37}$ Staphylus quotes from Gnapheus, Hypocrisis (1544), fol. A1 ${ }^{\mathrm{v}}$ (epigraph, entitled IN PARTEM COMICAM / Hexastichon, 'Six verses on the comical part'): 'Qui volet astrigeri conscendere laetus Olympi / Culmina, desierit hac ubi luce frui: / Comprimat affectus, saevique Cupidinis aestum, / Et facilis praestet, quae Metanaea dabit. / Nam dabit, ut superis sit pura mente litandum, / Quo ductu verae Palladis astra petas' ('Whosoever wants to ascend in a cheerful and optimistic mood the peaks of starbearing Olympus, / when he may no longer enjoy this earthly light, / he should repress his emotions and the fire of raging Cupid, / and he will easily attain what Repentance has in store for him. / For she makes sure you will do nothing but placate the gods with your cleansed spirit, / which enables you to reach the stars under the guidance of true Wisdom').

${ }^{38}$ Staphylus, Scriptum contra Apologiam Gnaphei, fol. 9r: 'Hypo[crisis] foli 1 manifesto affirmat vitam aeternam contingere, si quis comprimat affectus atque domet libidines. Non est quod errorem brevitate, ne [nec, VD] cessitate, excuset. Quae enim potuit illum tanta necessitas cogere ut invitus vitam aeternam ascriberet operibus? Non 
Besides the epigraph Staphylus derives another argument from Act IV, where it says that God may be placated wholly by 'the deliverance from desires, which a true and living faith brings about, a holy and spiritual withdrawal, and a true heart, together with gratitude towards God'. ${ }^{39}$ Staphylus states that these lines may refer to the sacrifice of the Eucharist, but even if they do Gnapheus is still wrong: unlike Catholics, Lutherans should believe that the Eucharist can only alleviate sin, but in no way appease God altogether. ${ }^{40}$ Possibly Staphylus wants to show that Gnapheus believes-and wants his public to believe-that a believer's way of living, such as no longer being tempted by desires (puritas affectuum), or his actions, like celebrating the Eucharist, are more important than his faith. In his accusation Staphylus cunningly omits the next lines of the passage, and not surprisingly these verses happen to repudiate Catholic sanctimony. Psyche, the protagonist of the play, is talking to her 'catechist' (catechista), the allegorical character Repentance.

That is why you tell me to shun the splendour of works, invented and forced upon us by Hypocrisy and her sisters, as if they would placate God and bring salvation, while the contrary is the case, because there is no salvation for hypocrites; on the contrary, you would rather see me

patiabantur versus, inquiet. Respondeo. Satius fuit cessare, quam agere nihil. Quid obstitit, quo minus, quod operibus, id fidei tribueret?' ('On the first page of his Hypocrisis Gnapheus clearly states anyone can attain eternal life, if he subdues his emotions and tames his lusts. Without rhyme or reason he excuses his error by means of brevity or carelessness. Without reason, for what necessity, however great, could have forced him to attribute eternal life to works? "The metre wouldn't let me" he will probably say. I answer him: "It had been better to fall short, than to do nothing at all. What kept you from attributing to faith, what you attributed to works?"').

${ }_{39}$ Gnapheus, Hypocrisis (1544), IV.5 (fol. 64): '[...] tum puritas affectuum, / Fides parit quam gnesia atque vivida, / Mentis sacer recessus, et fas pectoris / Cum gratiis deo, ut decebit, redditis.'

40 Staphylus, Scriptum contra Apologiam Gnaphei, fol. 9': 'Quod si fortassis Gnapheus eo decurrat ut dicat se intelligere sarrifitia eucharistica, tamen falsum et illud erit hisce Deum placari omnifariam. Non negarim quidem propter eucharistica sarrificia renatis mitigari paenas temporales, At Deum tamen eisdem placari omnifariam, est [...] Papistarum commiscentium doctrina legis atque Evangelii. Nam unica victima, qua Deus omnifariam placatur, est solus salvator Christus Filius aeterni patris' ('However, if Gnapheus resorts to the excuse that he meant the sacrifice of the Eucharist, then it will still be erroneous to believe that the Eucharist appeases God altogether. Not that I deny that the Eucharist alleviates temporary penalties, but to believe that the Eucharist appeases God altogether, that is the Catholic confusion of the doctrine of the Law and the Gospel. For the only sacrifice to appease God altogether is Christ, the only saviour and Son of the eternal God'). 
carrying this candle of all the good, so that all may know about my faith through my pious works and virtues. ${ }^{41}$

In the second edition of 1564 Gnapheus contrasts the works to which Staphylus objected (a spiritual withdrawal, the repression of emotions, a repentant and god-fearing soul) straight away with Catholic works such as 'incense, liturgies, and ceremonies, with which those priests of Baal repugnantly practice their religion'; and he no longer states they appease God altogether, but that they are simply more virtuous offerings than the Catholic ones. ${ }^{42}$

In short, Staphylus does not object to the passages that denigrate certain practices within the Church (how could he, as a self-respecting Lutheran), but he does find fault with Gnapheus's exposition of evangelical belief. Gnapheus can indeed be said to expound non-Lutheran views in certain lines, but these accusations cannot be maintained when the context of the passage and the play as a whole is considered. Staphylus seems to judge the play according to the letter, but disregards the spirit. Hypocrisis is obviously an anti-Catholic polemic, but it is a Lutheran catechism as well (or so will be argued below, though on this point opinions are divided). ${ }^{43}$

It seems Gnapheus was quite affected by the heresy trial, because he thoroughly revised the text of Hypocrisis before publishing it anew in 1564 (which happens to be the year in which Staphylus died), and he deleted or modified all offensive passages. The dedicatory letter of the reprint is an elaborate apology, in which Gnapheus refutes certain allegations, and asserts that he honestly does dramatize Lutheran dogmas (viz. on the Law and the Gospel) in his Hypocrisis. ${ }^{44} \mathrm{He}$ also

${ }^{41}$ Gnapheus, Hypocrisis (1544), fol. 64 (IV.5): '[...] Facessere hinc / Ergo iubes, operum nitelas, quas mera / Hypocrisis, suis stipata sororibus / Confingit, obtruditque nobis, ceu Deo / Placeant, salutem et afferant, cum nil minus / Faciant, salus quia hypocritis nulla obtigit, / Sed lampadem hanc omnis boni vis ferre me, / Quo liceat fides mea omnibus palam / Pietatis ex operibus et virtutibus.'

${ }^{42}$ Gnapheus, Hypocrisis (1564), fol. E3 ${ }^{v}$ (IV.5): 'Mentis recessum, affectuum / Repressionem, animumque poenitentia / Tractum et Deo gratum, esse victimas, quibus / illi litetur sanctius, quam thusculis, / Liturgiis et ritibus, quae flamines / Isti Baalis absonis colunt modis.'

${ }^{43}$ See Rädle, 'Theatralische Formen', pp. 280, 283, 286-87. He contends that Gnapheus contrasts Catholicism with a Schwenckfeldian 'individual religion' rather than with Lutheranism. So too Staphylus, who not only accuses Gnapheus of Catholic inclinations, but also of Anabaptism.

${ }^{44}$ Gnapheus, Hypocrisis (1564), fol. A3 ${ }^{\mathrm{r}-\mathrm{v}}$ : '[...] quod Tragicam eius partem attinet, in qua de lege, de iactata operum a nobis electorum fiducia et iudicio (quamvis sub Hypocrisis et asseclarum ipsius persona) agitur [...] Contra vero ubi in Comica 
attacks his prosecutor, who (as Gnapheus mentions in a final remark) has by that time left the Lutheran Church and returned to Roman Catholicism. ${ }^{45}$ Gnapheus's readership was the respublica literaria, the European network of humanist scholars, but the target audience of the 1564 reprint seems to have been the Lutheran elite specifically. The revised version was printed in Wittenberg, at the heart of the Lutheran Church. Gnapheus seems to have published it with the intention of rehabilitating himself within the Lutheran community after the disgrace of his excommunication. The Wittenberg printer probably welcomed work that discredited Staphylus, who had become a fervent opponent of the Reformation, and was engaged in a polemic against Melanchthon.

\section{HYPOCRISIS AND LATIN AND VERNACULAR TRADITIONS}

Like his other Latin plays, Gnapheus wrote Hypocrisis for educational purposes at the Latin schools where he taught. The plays were performed by his pupils with the intent of contributing to the spiritual and moral education of the pupil who watched or acted in the work, but also to broaden his command of Latin [...] in order to prepare him for a life of public service to the city or the state'. ${ }^{46}$ It is an imitation or emulation of 'the language, structure, and in some cases the plots of

huius scripti parte locum illum alterum de vera poenitentia, et fide in Christum (sub poenitentis et in eiusdem Christi perlitatione acquiescentis Psyches persona) tracto [...]' ('Concerning the Tragical part [of the play, VD], which deals with the Law, and with the boastful trust we place in the works we select for their magnificence, and our judgement [concerning these works, VD] (albeit in the person of Hypocrisy and her followers) [...] However, in the Comical part of this work, where I discuss the other side of true repentance, and belief in Christ (in the person of the repentant sinner Psyche, who takes comfort with the sacrifice of the same Christ) [...]').

${ }^{45}$ Gnapheus, Hypocrisis (1564), fol. A $5^{\mathrm{r}-\mathrm{v}}$ : 'Quam sortem longe indignissimam utinam ipse non etiam serio in seipso aliquando experiatur, si non ob hoc, quod calumniose adeo annis superioribus me praeter meritum persequutus sit, sed quod non ita dudum a vera religionis Christianae professione ad Antichristi Romani partes transfuga defecerit' ('I sincerely hope he meets the same most undignified fate [that the avenging Furies punish his hypocrisy, just as happens in the play, VD], if not because all those years ago he made my life a hell with his false accusations, then because he quite recently seceded from the true Christian religion to go over to the party of the Roman Antichrist'). Staphylus converted to Catholicism in 1552.

${ }^{46}$ Parente, Religious Drama and the Humanist Tradition, p. 9. 
Greco-Roman theatre'. ${ }^{47}$ The subject matter, however, is always Christian, and often biblical.

Parente admits that humanist religious theatre was influenced by other, vernacular, forms of theatre. However, the interplay between sixteenth-century Latin drama and vernacular theatre is much more profound than the 'cunning devils, allegorical figures, and heroic saints from the late medieval tradition' he mentions. ${ }^{48}$ This is especially so in Gnapheus's Hypocrisis, but his other plays also contain elements that can only be explained and appreciated as borrowings from the vernacular tradition. ${ }^{49}$ Although Hypocrisis may be written in Latin and (with its five-act structure) cast in the form of Roman comedy, the themes (or narrative motifs) seem to be in line with the vernacular morality play, a genre practiced in the Low Countries, France, England and the German lands. This is not something out of the ordinary, ${ }^{50}$ but it may imply that Gnapheus's Latin plays are not only as emphatically moralistic and didactic as vernacular morality plays, but also just as critical and satirical. ${ }^{51}$

The most defining characteristic of the morality play is allegory, which brings to life an abstract concept or authority. ${ }^{52}$ The main use

${ }^{47}$ Parente, Religious Drama and the Humanist Tradition, p. 7.

${ }^{48}$ Parente's definition seems to be based on later humanist religious drama, written after the 'codification of the humanist style in the late Renaissance poetics of Julius Caesar Scaliger (1561) en Gerardus Vossius (1647)', in which 'such symbiotic exchanges were discouraged', p. 6. Vernacular drama may have left hardly any traces in the later 'neo-classical style of the humanists', Baroque drama written in Latin and the vernacular (the 'cunning devils' etc.), but in the earlier examples of Latin drama its influence is much greater.

${ }^{49}$ For example, the allegorical character Philautus ('Self-love') of Acolastus as a personified vice who leads the protagonist astray; the allegorical characters Morosophus and Sophia in Morosophus, who represent feigned and true wisdom, and the theatrical form of Triumphus Eloquentiae, that may be borrowed from rhetorician processiespelen ('procession plays'). See Macardle, The Allegory of Acolastus, p. 8; Worp, Geschiedenis van het drama en het tooneel, 1, p. 235 and Demoed, Wie van gwaar houdt, pp. 118-126, 134, 167.

${ }^{50}$ See for example the Latin translations and adaptations of Elckerlijc (Every-man), Bloemendal, Transfer and Integration.

${ }^{51}$ On the moralistic and didactic nature of vernacular and Latin moralities, see Waite, Reformers on Stage; Moser, 'Maria verklaard'; Parente, Jr., Religious Drama and the Humanist Tradition. On the interplay between the moralistic and the polemical and satirical nature of French religious moralities written during the reformations, see Doudet, Statuts et figures. On the polemical and satirical nature of German drama, especially the Latin moralities of Naogeorgus, see Walz, Deutsche Literatur der Reformationszeit, pp. 117-18; Könneker, Die Deutsche Literatur der Reformationszeit, pp. 173-83; Parente, Jr., Religious Drama and the Humanist Tradition, pp. 8, 74-76.

${ }_{52}$ Ramakers, 'Dutch Allegorical Theatre', pp. 127-28. 
of allegorical tool in drama is personification, which makes the abstractions livelier: it represents immaterial things and relationships with (real and material) objects, characters and their actions. Take for example the protagonist of a standard morality play such as the famous Elckerlijc, translated into English as the-equally famous-Everyman: he represents mankind. Some morality plays have two protagonists, together representing mankind: one of them will (eventually) keep to the straight and narrow path and will be saved; the other will go astray and face damnation. The Mankind figure (or figures) is usually seduced by personified vices into going astray. Personified virtues on the other hand come to the rescue. Furthermore, in morality plays, an allegorical name (and thus meaning) is attached to objects (for example props and costumes) and to places. The characters can be liberated from their 'allegorical imprisonment'-for example, by changing their allegorical costume. In Elckerlijc, for instance, the protagonist Elckerlijc, after he has been to confession, done penance, and repented his former life, receives a robe which represents his repentance ('tCleet van Berouwenissen', 'Garment of Repentance'). ${ }^{53}$ The same thing happens in Hypocrisis: the protagonist Psyche lays down her long robe, which represents her hypocrisy; and a little later she reappears on stage in a white robe representing her uprightness. ${ }^{54}$

Allegory was a commonly used 'didactic technique', through which 'often extremely abstract questions of religion, morality and attitudes to life can be visually and comprehensibly represented to a wider audience. ${ }^{55}$ Moser explains that playwrights communicate moral lessons indirectly: as the protagonist is instructed by another character, so the spectators are taught by the author of the play through the characters. ${ }^{56}$ Besides their didactic function morality plays (and other forms of allegorical drama) were often employed to expose general vices and

${ }^{53}$ Elckerlijc, 601-10. Here the idea (repentance) is turned into an object, instead of a person.

${ }_{54}$ Gnapheus, Hypocrisis (1564), fol. E2 ${ }^{\mathrm{v}}$ (IV.3), where Repentance orders Psyche to change her dress: 'Primo ergo pone Syrma (quod trahis) longum. / Hinc rosidae fuco genae abluantur, ne / Quid Hypocriseos huc adferatur' ('To begin with, lay aside the robe you are wearing. Then you should wash the make-up from your rosy cheeks, so that you will not take along any Hypocrisy with you over here'). And fol. F1 ${ }^{\mathrm{r}}$ (V.5): 'Nivea innocentiae stola' ('a white garment of innocence'). Psyche's antagonist, Hypocrisis, on the other hand, is deprived of her white costume.

${ }_{55}$ Ramakers, 'Dutch Allegorical Theatre', p. 129.

${ }_{56}$ Moser, 'Maria verklaard', pp. 246-47. 
satirize historical figures. ${ }^{57}$ Especially during the performance of a play, the gestures, speech and costume can make it crystal-clear whom exactly is being attacked under the veil of allegory, however vague the dramatic text may be. ${ }^{58}$

And so does Hypocrisis: through the character Hypocrisy the play indisputably ridicules the Catholic faith.$^{59}$ How do we know Hypocrisy must be interpreted as the Church? As will be argued later, the mere mention of the name Hypocrisy already points towards this interpretation. Gnapheus makes the identification explicit in the scene in which Hypocrisy laments that she is being condemned, but only through textual references.

Where have the armies of my order gone, and the innumerable cohorts of my sworn-in Monks and Nuns? Where are the flatterers and countless servants, from among the colleges of the Cardinals raised to the purple, who never left my side while I was doing well? Where are the Jesuits, the avengers of my honour? ${ }^{60}$

Spoken remarks such as these probably easily escaped attention during a performance, but the reference is also clarified by visual means. Even to an audience unable to understand one word of Latin, the antiCatholic sentiments could be deciphered through imagery. On stage 'objects, characters and actions with "meanings" are actually made visible' ${ }^{61}$ Gnapheus had to make sure that his audience understood the code, and would be able to decrypt the link between object, character or action, and what they represented. For example, in Act II, Scene 3 the character Hypocrisy approaches the temple where she often comes and prays: it looks like a typical Roman Catholic church. Hypocrisy might merely be describing the place to the public, but this may also

\footnotetext{
${ }^{57}$ See Doudet, 'Statuts et figures'. Spaans, on the other hand, asserts that the allegorical nature of moralities functions as a veil, and prevents satire and possible controversial readings by the audience, in 'Public Opinion or Ritual Celebration of Concord'.

${ }^{58}$ Doudet, 'Statuts et figures', p. 18. On the importance of visual elements, see Ramakers, 'In utramque partem vel in plures', pp. 198, 207-13, 216-17.

${ }^{59}$ Rädle, 'Theatralische Formen', pp. 280-88.

${ }^{60}$ Gnapheus, Hypocrisis (1564), fol. D8 ${ }^{\mathrm{r}}$ (IV.1): '[...] Ubi nunc mei / Sunt ordinis centuriae, innumera cohors / Coniuratorum? Nonnos et Nonnas loquor? / Ubi sunt colaces et ciniflones plurimi, / E purpuratorum Patrum collegio, / Qui me re salva circumstabant undique? / Ubi Iesuitae, honoris nostri vindices?' The Jesuits do not yet appear in the 1544 print.

${ }^{61}$ On the importance of visual elements, see Ramakers, Dutch Allegorical Theatre, pp. $129-30$.
} 
be a description of the actual décor. If so, the public would be able to recognize the setting for a Catholic church through visual indications, and readily identify Hypocrisy with Catholicism.

I am approaching the Chapel. My heart leaps up with joy, whenever I look round. For here my sanctimony can be best seen. Everywhere I turn my eyes, there are beautiful paintings, statues, the 'armour' of the priests and all the sacred things. I can hear the organ playing sweetly. Here I live and reign. Here I am worshipped as God. ${ }^{62}$

And if the public still does not understand, then Hypocrisy's costume and her actions will give further hints. Gnapheus's public was familiar with allegorizations and personified abstractions, whom it recognized by their dress and attributes. Clothing was a motif in literature, the visual arts and drama; it was also omnipresent in religious ceremony. Hypocrisy is wearing a snow-white dress and bridal veil, ${ }^{63}$ which must have reminded the audience of the alb, a white vestment worn by the Catholic clergy, and the nun's headdress. Erasmus makes use of the alb and its connotations in his Praise of Folly, when he satirizes popes, bishops and cardinals: their behavior does not correspond to the white dresses representing their innocence. ${ }^{64}$ In painting both the abstractions Catholicism and Hypocrisy were personified by a woman dressed in white; the latter, Hypocrisy, appearing as a leper or wolf beneath her clothing. ${ }^{65}$ A rhetorician allegorical play, Dwerck der Apostelen cap. 3, 4 en 5 ('The Acts of the Apostles Chapters 3, 4, and 5', before 1539), features two personified vices, who represent the sanctimony and materialism of the Pharisees (implying the same vices of

${ }^{62}$ Gnapheus, Hypocrisis (1564), fol. C3 ${ }^{\text {r }}$ (II.3): 'Approximo Larario. Pol gestiens / Animus novo mihi gaudio percellitur, / Quoties illud contemplor. Sanctimonia / Enim mea hic vel spectatissima redditur. / Oculi et pascuntur hic pictura nobili, / Statuis, panoplia flaminum, atque re sacra. / Aureis demulcent organôn modulamina. / Hic vivo et regno. Hic numinis loco color.' '[N]uminis loco' in the last line can also be translated as 'instead of God'.

${ }^{63}$ See for instance Gnapheus, Hypocrisis (1564), fol. C6 ${ }^{\mathrm{r}}$ (III.1), where the Fury Ate comments on Hypocrisy's costume: 'Quid, quod nive hybernia albior vestitus est?' ('What is the reason her dress is whiter than snow?'). And fol. C4: 'candido (...) flammeo' ('a white bridal veil'). This white dress and bridal veil (and Psyche's 'white garment of innocence', see note 54) could be connected to the theme of the 'ecclesia sponsa Christi', the Church as Christ's bride, based on an allegorical reading of the Song of Songs, in which the bride stands for the Church, or the soul of the individual believer (Psyche is Greek for 'Soul'), and the groom represents God or Christ.

${ }^{64}$ Erasmus, Praise of Folly, 57 and 58, ASD IV-3, pp. 170.739-172.767.

${ }^{65}$ Cesare Ripa, Iconologia of Uytbeeldinghen des Verstants (Fede Catholica and Hippocresia). 
the latter-day Catholic clergy). ${ }^{66}$ One of them, Schoon Ypocrijt ('Beautiful Hypocrite'), displays 'on his white robe virtues such as poverty, humility, devotion, and fasting, while under the cloth he is dressed as a devil, with a roll displaying the vices' ${ }^{67}$ Compare his appearance to Hypocrisis's, about which she boasts in her defense: 'I do not think I have to tell you about the virtues I am adorned with. Here you can see my chastity, there my humility. Around my chest go faith, hope and love. Nor do I have to tell you the meaning of these words, loincloth and veil' ${ }^{68}$ Hypocrisy too, will be shown to be quite different underneath her white robe. Hypocrisy's actions complement her looks: she can be seen saying the rosary, and the ritual cleansing Asperges me is actually enacted on stage, both characteristic of Catholicism. ${ }^{69}$ In order to substantiate my claims of the play's confessional-polemic nature and its Lutheran content, a summary and an analysis of Hypocrisis will be given.

\section{The Morality of Hypocrisis}

The play's protagonist Psyche (Greek for 'Soul') is said to represent the sinful human soul, ${ }^{70}$ and she can be compared to the Mankind figure of morality plays. Apollo, the Muses, and the Graces (patrons of the humanities) will bring her to trial because of her marriage to Cupid. Cupid personifies the temptations to which the human soul is exposed. ${ }^{71}$ The marriage must be interpreted as Psyche's surrender to food, alcohol and sex, and her neglect of her studies. Psyche must

\footnotetext{
${ }^{66}$ Waite, Reformers on Stage, pp. 131-33.

${ }^{67}$ Waite, Reformers on Stage, p. 132. Hummelen, De sinnekens in het rederijkersdrama, pp. 43,45 .

${ }^{68}$ Gnapheus, Hypocrisis (1564), fol. D3' (III.3): 'Ut interim ne addam, quibus / Quam varie ornata sim virtutibus. Hic mea ecce castitas, / Est hic humilitas. Pectus ambiunt fides, spes, charitas, / Inscriptio haec, lumborum cinctus, flammeum quod arguunt.'

${ }^{69}$ Gnapheus, Hypocrisis (1564), fol. C6 ${ }^{\mathrm{r}}$ (III.1); fol. C6 ${ }^{\mathrm{v}}$ (III.2).

${ }^{70}$ Gnapheus, Hypocrisis (1564), fol. A7 ${ }^{\mathrm{v}}$ (Dramatis personae): 'Psyche anima est hominis peccatoris, ingenii et eruditionis suae dotibus ad fastum, luxum, et alia nequioria abutentis' ('Psyche is the sinful human soul, abusing the gifts of her talent and knowledge on order to attain pride, luxuriousness, and other depravities').

${ }^{71}$ Gnapheus, Hypocrisis (1564), fol. A7 (Dramatis personae): 'Cupido Veneris filius amorem, reliquosque affectus et libidines signat' ('Cupid [is] Venus's son and represents love, the other passions and lust'). The 1544 print is somewhat clearer on his nature: 'Veneris filius, affectus malos et vicia animi signat' ('[he is] Venus's son and represents bad feelings and spiritual shortcomings') (fol. 10).
} 
defend her licentious lifestyle before Jove, who is sometimes referred to as Deus or Numen, and thus represents the Christian God.

In the first act we encounter a fearful Psyche who knows she is guilty and has sinned. A Fury from hell, Alecto, tries to drive her to despair and force her to commit suicide. Alecto would have succeeded were it not for the intervention of Genius, Psyche's tutelary spirit. He tells her that God is merciful and pardons even the worst sinners. Psyche's despair and Genius's ensuing hopeful words remind us of Luther's dogma of the Law and the Gospel. Psyche then asks the character Hypocrisy to plead her case in court. Because Hypocrisy represents the Roman Catholic Church, this stage action signifies that Psyche (Mankind) asks the Church to intervene on her behalf. Of course (bearing in mind Gnapheus's dislike of the Church) Hypocrisy will fail.

Hypocrisy is not very eager to defend Psyche, but in the second act she is tricked into acting as Psyche's lawyer by the personified vices Ate and Alecto, two Furies from the Underworld who have disguised themselves as Hypocrisy's trusted followers 'Religiousness' ('Religio') and 'Doctrine' ('Disciplina'). Ate and Alecto can be regarded as the humanist counterparts to the personified vices of Dutch allegorical drama; just like the vices, or sinnekens, of Dutch rhetorician theatre, Ate and Alecto act in pairs (even though the Furies from Greco-Roman mythology are usually a threesome), they are devils from hell (in this humanist drama appropriately transformed into Furies from Hades), and must disguise themselves when confronting the protagonist(s). ${ }^{72}$ Furthermore, their names, consisting of a noun which is in itself neutral, accompanied with a pejorative adjective ('feigned Religiousness', and 'false Doctrine') are similar to the Dutch convention of the sinnekens as well. ${ }^{73}$

The third act encompasses the actual trial (III. 3). The so-called 'Trial in Heaven' or the 'Satanic Trial' of vernacular morality plays may have inspired Gnapheus to write this scene. In the Trial in Heaven, Righ-

\footnotetext{
${ }^{72}$ Hummelen, De sinnekens in het rederijkersdrama, pp. 63-64, 111.

${ }^{73}$ Hummelen, De sinnekens in het rederijkersdrama, p. 35. Gnapheus, Hypocrisis (1564), fol. A7 (Dramatis personae): 'Alecto Furiarum infernalium una, sub fictae interim disciplinae persona, quam induit, ultrix est male gestae rei conscientia' ('Alecto, one of the infernal Furies, is [represents, VD] the avenging conscience, while acting as feigned Doctrine'). And: 'Ate Turbarum et rixarum parens, quae et falsae religionis personam interim induit, mali omnis autorem cacodaemonem repraesentat' ('Ate, the mother of confusion and quarrels, who also performs the part of false religiousness, represents the origin of all evil, the devil').
} 
teousness and Truth plead against the defendant, whereas Mercy and Peace act in his or her favour; in a Satanic Trial a devil and Mary state their cases before God's throne. ${ }^{74}$ Hypocrisy fails to persuade Jove of Psyche's innocence (a denial of the Church's mediation between mankind and God). Worse still, she is found guilty herself, and condemned for her hypocritical behaviour and for distorting Christian religion.

For you, Hypocrisy, were always eager to act your part by means of bad fraud and ruse, all too mendacious (whether it be your words, appearance or customs), spreading threats and inflicting death upon good men. Secondly, because you have enthralled Psyche in such a way, that she perverted and neglected the true worship of God. ${ }^{75}$

She will be dragged off to Hell, to be punished by the very same devils Ate and Alecto who seduced her earlier. Psyche, on the other hand, seeks refuge in the 'altar of Mercy' (ara Misericordiae). This 'object', or prop, and the allied 'action' probably represent Psyche's repentance of her crimes, and an appeal to Jove's, or God's, mercy. God's mercy will indeed prove greater than his righteousness.

Up until now Psyche has been quite apprehensive, but now, in act IV, she is relieved because, at least for her, the trial has turned out well. It would appear that Gnapheus dramatizes the Lutheran doctrine of the Law and Gospel: the Law, that is, the Old Testament, and its righteous God instill fear, for no one can ever hope to meet the requirements of the laws of the Old Testament. The Gospel, on the other hand, presents Psyche with a merciful and forgiving God (represented on stage by the ara Misericordiae). Depictions of the antithesis of the Law and the Gospel occurred most frequently in Lutheran pedagogic propaganda. ${ }^{76}$ These kinds of theological broadsheets show that, in addition to their largely negative assaults on the Catholic Church, Lutherans tried to define their own evangelical beliefs more and more in positive terms. ${ }^{77}$ It must have been a familiar theme, all the more reason why Gnapheus dramatized it.

${ }_{74}^{74}$ Ramakers, 'Dutch Allegorical Theatre', p. 134.

75 Gnapheus, Hypocrisis (1564), fol. D5 ${ }^{\mathrm{v}}-\mathrm{D} 6^{\mathrm{r}}$ (III.4): 'Quoniam tu, Hypocrisis, vel a puero unice / Id tibi studio habuisti, ut histrionicam haud sine / Fuco et dolo faceres malo, per omnia / (Nempe ore, veste, moribus) mendax nimis, / Spirans minarum et caedium in bonos viros. / Deinde hanc tuam quia coelitus satam Psychen / Sic fascinasti, ut gnesio cultu Dei / Adulterato et negligentius habito.'

${ }^{76}$ Scribner, For the Sake of Simple Folk, p. 228.

77 Scribner, For the Sake of Simple Folk, pp. 216-19. 
Psyche is acquitted, provided that she will not return to Cupid, and only if she succeeds in asking the character Repentance (Metanoea, or Poenitentia) to lead her to the Litae, the 'offspring of Jove' (prolem Iovis), who therefore represent the Son of God, Christ. ${ }^{78}$ Psyche is now what the Lutherans might call a 'justified believer', and only now may she (and ought she to) perform good works. ${ }^{79}$ She immediately does so: she feels pity for the poor and gives alms. However, even a justified believer remains a sinner, and must keep on fighting his or her desires. ${ }^{80}$ This is enacted on stage by strife between Psyche and her former husband Cupid: Psyche must continue to prove that she no longer cares for Cupid, while continuously trying to withstand his attacks. In a morality play the protagonist progresses from a state of sin or ignorance to a state of mercy or understanding. This process is represented as a pilgrimage. Several scenes from Hypocrisis make clear that Psyche's progress from her sinful life (her marriage with Cupid) to the altar of Mercy, Repentance, Wisdom and Christ, and eventually heaven, must be regarded as a long and difficult journey. See, for example, how Psyche describes her progress to Repentance: 'Now that I have evaded the many chasms along the way and have overcome these narrow passes, I wonder whether I will truly learn to know Repentance, in such a humble shack, in such a turf hut'. ${ }^{81}$ In contrast to most people, who are deterred by Repentance's earnest appearance, Psyche enters Repentance's humble dwelling. Repentance tells Psyche to lay aside her clothes and make-up, which represents her liberation from Hypocrisy, and thus Catholicism. ${ }^{82}$

${ }^{78}$ The Litae are the (personified) Prayers of sorrow and repentance. The fact that they represent Christ is made even more explicit in Gnapheus, Hypocrisis (1564), fol. E8 ${ }^{r}$ (V.4), where Psyche says: 'Christum Domini quaero hac casa reconditum. / Quanquam Litarum sub colendo nomine' ('I am looking for Christ, the son of God, hidden in this house, even though he may be worshipped under the name of the Litae').

${ }^{79}$ Luther taught that man is justified by faith alone (sola fide), and not by doing good works. But once an individual is justified, he or she does not remain so without charitable works. See for example Lindberg, Reformation Theologians, p. 61. Justification is God's act of declaring righteous an unrighteous sinner.

${ }^{80}$ Gnapheus here dramatizes one of Luther's best-known phrases: 'simul iustus et peccator' ('at once justified and sinner', or: 'simultaneously sinner and saint').

${ }^{81}$ Gnapheus, Hypocrisis (1564), fol. E2 ${ }^{v}$ (IV.3): 'Postquam viae istius crepidines multas / Evasi et has angustiis penetravi, / Mirabor, hic si Poenitentia est vere / Discenda, sub tam humili casa atque item glebis / Tecto lare.'

${ }^{82}$ Psyche's dress is called a syrma, which was worn by actors in Greek tragedy. In Erasmus's adage Sileni Alcibiadis, which comprises an extensive critique of the 
In the fifth and final act Repentance guides Psyche towards the humble dwelling of the Litae, recognizable only by a cross, and located at the foot of a hill. The Litae, or Christ, will not appear on stage, but Pallas, divine Wisdom, guards their temple against hypocritical contrite sinners. Pallas permits Psyche to enter. After her peaceful death (contrasted to Hypocrisy's bitter end), she enters heaven. In a tableau vivant, a common dramatic technique in Dutch rhetorician drama, we see Psyche kneeling before God, or Jove, who blesses her. ${ }^{83}$

\section{Hypocrisis AND THe LUtheran Reformation}

Hypocrisis is both a satirical invective against the Church, and a dramatized Lutheran catechism, although on this last point the Lutheran theologian Staphylus fervently disagreed. An analysis of the satirical, anti-Catholic sentiments will show how Hypocrisy, and with her the Church, is represented on stage. Gnapheus refers to widely used motifs and ways of representing them: he identifies the character Hypocrisy, and thus the Church, with the hypocrites and Pharisees of the gospels; moreover, he brutalizes and demonizes the Church. Gnapheus was not the only one to do so.

The play emphasizes Hypocrisy's outward appearance, representing the Church's pomp and circumstance. For example, before appearing in court, Hypocrisy dresses up, trying to bedazzle her judge, or in other words to deceive Jove or God himself. ${ }^{84}$ And then there is the temple or shrine, where Hypocrisy is worshipped as if she were God, which looks suspiciously like a typical Roman Catholic church. By itself this temple or shrine means nothing but in comparison to the dwellings of Repentance and the Litae, or Christ, two contrasting Churches appear: a richly decorated Catholic one, and another, rather

pomp of the Church, the clergy is said to wear a tragic costume ('ornatum tragicum', ASD II-5, p. 180.433-34).

${ }^{83}$ Gnapheus, Hypocrisis (1564), fol. $\mathrm{F}^{\mathrm{r}}-\mathrm{F}^{\mathrm{r}}$ (Peroratio per Calliopium, 'Epilogue by Calliopius').

${ }^{84}$ See also Gnapheus, Hypocrisis (1564), fol. C6 ${ }^{\mathrm{r}}$ (III.1), where Ate tells the public what is happening behind the scenes: 'Stringit comam, faciem lavat, vultum oblinit / Ceu purpurisso. Flammeum induit novum, / Pudenda cordis aureo at strophio tegit. / Quid, quod nive hybernia albior vestitus est? [...] Videte, quam speciosa cultu appareat!' ('She is doing her hair, washing and making up her face. She puts on a new bridal veil, and covers her breasts with a golden chest ornament. What is the reason her dress is whiter than snow? Look, how fancifully dressed she appears!'). 
plain one. For example, after Genius has shown her the way, Psyche wonders whether she may find Repentance in such a humble shack, in such a turf hut'. ${ }^{85}$ This confrontation is reminiscent of Lutheran pamphlets that juxtapose the Roman Catholic Church with an evangelical one, such as the well-known and influential Passional Christi und Antichristi, which depicts and contrasts the simple life of Christ with the extravagant behaviour of the Pope. ${ }^{86}$ In the pamphlets as well as in Gnapheus's play the 'humility', 'simplicity' and 'unworldliness of Christ' or the new evangelical Church, are contrasted with 'the vices of pride, pomp and desire for possession' of the Roman Catholic Church. ${ }^{87}$ The religious message that the pamphleteers and the playwright Gnapheus want to convey to their public is the difference between true and false Christianity, Lutheranism and Catholicism.

The play also highlights Hypocrisy's sanctimony, that is, her reliance on works. Gnapheus's Hypocrisis contains several enumerations of good works. For example, when the disguised Furies try and persuade Hypocrisy to appear before Jove, they remind her of her many good deeds, such as her pilgrimages, and the persecution and execution of heretics. ${ }^{88}$ Their whole speech is delivered tongue-in-cheek, but Hypocrisy takes the bait. During the trial she repeats Ate's tactics, and recounts the good works Psyche has done, in the hope that Jove will pardon her: 'What about her grand works? What about the pilgrimages to Jerusalem? What about redeeming souls from Purgatory? What about the palms, the singing, incense, and all sorts of holy works? ${ }^{89}$ Apart from these catalogues, Hypocrisy also performs Catholic customs and rituals on stage: she recites the rosary, and says or sings Asperges me just before the trial starts.

${ }^{85}$ Gnapheus, Hypocrisis (1564), fol. E2 (IV.3): 'sub tam humili casa atque item glebis / Tecto lare.'

${ }^{86}$ The pamphlet consists of 13 pairs of woodcuts of Lucas Cranach and an accompanying explanation written by Melanchthon. It was first published in Wittenberg 1521. Scribner, For the Sake of Simple Folk, pp. 149-57.

${ }^{87}$ Scribner, For the Sake of Simple Folk, p. 155.

${ }^{88}$ Gnapheus, Hypocrisis (1564), fol. C4 $4^{\mathrm{r}-\mathrm{v}}$ (II.3).

${ }^{89}$ Gnapheus, Hypocrisis (1564), fol. D3 ${ }^{\text {r }}$ (III.3): 'ubi tum illius sunt labores maximi? Ubi peregrinationes ad Solymorum limina? / Ubi umbrarum ex teterrimi Orci faucibus redemtio? / Ubi festae frondes, cantus, thura, operosaque omne genus sacra?' See also Gnapheus, Hypocrisis (1564), fol. C2 ${ }^{\mathrm{r}}$ (II.2), where Hypocrisy complains about her predicament, undeserved after 'so many good offices, fasting, Psalms, castigation, formulas, and liturgies' ('tot curas, ieiunia, / Psalmos, flagra, cantus et liturgias'). 
From a Protestant point of view Hypocrisy's outward appearance and her sanctimony are mere hollow ceremonialism, and they will indeed prove to be of no avail; despite her looks and all her works, Hypocrisy will not successfully defend Psyche, and in addition she is found guilty herself. The Catholic 'paradigm of salvation' that Hypocrisy puts into practice leads straight to hell.

\section{Pharisees}

Empty ritualism was also ascribed to the new testamentary Pharisees. In anti-Catholic or anti-clerical literature the Catholic clergy and the Pope are often identified with the Pharisees. For example, in a rhetorician tafelspel (table or dinner play) entitled Prochiaen, Coster en Wever ('Parish Priest, Sexton and Weaver', 1538-1540), the priest says that Lutherans (such as his antagonist, the weaver) no longer attend confession but rebel against the authorities, do not perform good works, seldom go to church, do not venerate saints, and call priests like himself scribes and Pharisees (Ten vi. Seggen dat wij Priesters Scrijben zijn en Pharizeen, 'In the sixth place, they say that we Priests are nothing but Scribes and Pharisees'). ${ }^{90}$ The same identification frequently recurs in Luther's writings. For instance: 'the Pope does as the Pharisees used to do' ('Sicut papa facit, ita faciebant Pharisaei [...]'). And: 'If, on top of it all, they even become tyrants and kill the pious because of the Gospel, then a Shepherd [that is, a Priest or Bishop, VD] is no more than the devil himself. Back then the Pharisees and Scribes behaved in such a way, but right now the Pope and the Bishops, who have for a long time neglected the gospel and, made into wolves, put in its place their own traditions. Now they even persecute and kill the faithful because of the Gospel, which they should teach instead. Therefore the charade of the Pope, Cardinals and Bishops, who may be resembling Bishops, but in fact are wolves and even devils in the Church, is most terrifying. ${ }^{91}$

${ }^{90}$ Van Dis, Reformatorische rederijkersspelen, pp. 162.405-26. See also Waite, Reformers on Stage, pp. 127-31.

${ }_{91}$ Luthers Werke: kritische Gesamtausgabe, 38, p. 493.8, and 39/2, p. 73.12-13: 'Huc si accedat, ut etiam tyranni fiant, et propter verbum occidant pios, Iam nihil amplius esse Pastor, quam ipse diabolus. At tales fuerunt tunc Pharisaei et Scribae. Nunc autem Papa et Episcopi, qui iam dudum verbum neglexerunt in Ecclesia, et loco eius suas traditiones, lupi facti, intruserunt. Nunc etiam persequuntur et occidunt fideles propter verbum, quod ipsi ex officio docere tenentur. Horribilissima est igitur species ista Papae, Cardinalium, Episcoporum, qui larvati sunt Episcopi, re vera lupi 
Hypocrisis is not the first text in which Gnapheus used the motif. In the first dialogue of Gnapheus's pamphlet Een troost ende spiegel, the two spokesmen, Tobias and Timotheus, criticize the greed of their chaplain: he may appear a 'good evangelical', but he is no more than a 'hypocrite in disguise'. ${ }^{92}$ A little later the chaplain, and the Roman Catholic clergy in general, are compared to the 'feigned hypocrites and whitened sepulchres' of St. Matthew's Gospel. ${ }^{93}$ Subsequently, the Catholic clergy and the scribes are bracketed together ('Priests and scribes', 'Papen ende scriftgeleerden'), and the scribes and Pharisees are identified with the clergymen of Gnapheus's own day. ${ }^{94}$

Given that the Pharisees and hypocrites from St. Matthew's Gospel were often linked to the clergy and the Church, it is likely that spectators immediately identified the character Hypocrisy with the Pharisees by her name alone, and from there with the empty rituals of the Catholic Church. Readers (and potential buyers) on the other hand must have guessed the Protestant nature of the play as well: Hypocrisis is quite a revealing title. The Index personae further encourages this identification: 'Hypocrisy, that is, feigned sanctimony of life and religion, as can be deduced from her name' ('Hypocrisis, Simulata est vitae et religionis sanctimonia de nomine').${ }^{95}$ But the subtitle and motto on the 1564 title page in particular point Gnapheus's readership in the right direc-

et ipsi diaboli in Ecclesia.' Both stemming from works on St. Matthew's Gospel, from which Gnapheus borrowed the motto in the 1564 revised version of Hypocrisis.

${ }_{92}$ Gnapheus, Een troost ende spiegel, fol. A3 ${ }^{\text {r: }}$ 'Tobias: Wat hoor ic nv, Ick hadde ghewaent dattet een goet Euangelicsh man gheweest hadde, want hi holt hem so heylichlic opten stoel, dat ick mi daer af verwonderde, maer ic sie wel dattet niet dan een groot beueynst hypocrijt en is, Hi plach emmers selfs op die preecstoel dicwils te vercondighen, datmen hem niet sparen en solde, hy wilde oock int middel vander nacht geerne opstaen van zijn bedde' ('What do I hear now? I thought he was a good evangelical man, for he behaves so holily in the pulpit, that I was quite impressed, but now I see that he is nothing but a great hypocrite in disguise, for he himself in his pulpit has often stated that he should not be spared, and would be gladly roused from his bed in the middle of the night'). Bibliotheca Reformatoria Neerlandica, 1, p 154. Now, however, the chaplain will not come and visit their sick friend Lazarus.

${ }^{93}$ Gnapheus, Een troost ende spiegel, fol. A3 ${ }^{v}$ : '[...] beueynsde hypocrijten, ende beschilderde grauen [...].' Bibliotheca Reformatoria Neerlandica I, p 155.

${ }^{94}$ Gnapheus, Een troost ende spiegel, fol. A5 ${ }^{\mathrm{r}}$ : '[...] die Scriben ende Phariseen, die doe ter tijt alsoo stonden op haer sacrificien, feestdagen, tienden ende offerhanden, ghelijcken Hedens daghes ons Papen voor dalder heylichste ende weerdichste werc holden, missen ende ghetijen te lesen, ende den heilighen dach te vieren' ('the Scribes and Pharisees, who at that time insisted on their sacrifices, feast days, tithes, and offerings, just like today our Priests consider it as most holy and worthy to read mass and hours, and observe the Sabbath'). Bibliotheca Reformatoria Neerlandica, 1, p. 158.

${ }^{95}$ Gnapheus, Hypocrisis (1564), fol. A7 ${ }^{\mathrm{v}}$ (Index personae). 
tion: 'Hypocrisy. A Tragicomedy about the false Religiousness, feigned Discipline and punishment of an uncommonly Pharisaical Hypocrisy' (HYPOCRISIS. / DE HYPOCRISIS / PRAESERTIM PHARISAICAE FAL- / sa Religione, ficta Disciplina et supplicio (...) Tragicomoedia). Hypocrisy's epithet 'uncommonly Pharisaical' (praesertim pharisaica) points to the Pharisees. The epigraph on the same page, a quotation from St. Matthew's Gospel, completes the identification. ${ }^{96}$

\section{Foxes, wolves and the papal ass}

Gnapheus brutalizes the character Hypocrisy, and thus the Church, through animal allegory, though he does so only once, ${ }^{97}$ during Hypocrisy's exposure, shortly after the delivery of her speech in defence of Psyche, or humankind. Mercury, the messenger of the gods, is speaking directly to the audience.

You can see, good citizens, that Hypocrisy, now that her mask has been torn off, is deformed by the monsters of her vices: here lies the dog, there the pig rolls about in the mud, and she is shedding crocodile tears. Her heart is beset by the Bear, Tiger, Lion, wolf, snake and Panther. Not unlike Proteus [a god from Greco-Roman mythology, who could assume every shape and form, VD] she changes into thousands of monsters. ${ }^{98}$

Animal allegory tends toward personification, and indicates that Hypocrisy has the same characteristics as the animals mentioned: the

\footnotetext{
${ }^{96}$ Gnapheus, Hypocrisis (1564), fol. A1': 'Matth. XXIII. / Vae vobis Scribae et Pharisaei, Hypocritae, qui similes estis sepulcris dealbatis, quae foris quidem apparent speciosa, intus vero plena sunt ossib[us] mortuorum, omnique spurcitia. / Sic et vos quidem apparetis hominibus iusti, intus autem pleni estis hypocrisi atque impietate' ('Matthew 23, 27. Woe unto you, scribes and Pharisees, hypocrites! for ye are like unto whited sepulchres, which indeed appear beautiful outward, but are within full of dead men's bones, and of all uncleanness'). Translation KJV.

${ }^{97}$ Hypocrisy is twice closely linked with foxes. Gnapheus, Hypocrisis (1564), fol. $\mathrm{C}^{\mathrm{v}}$ (II.2), where Hypocrisy asks herself what will happen if word went round that she is not willing to help Psyche, one of her most loyal followers: 'Quis illic sit locusve, honosve / Hypocrisi, nisi apud Crocodeilos forsan meos / Et summos fingendi artifices vulpeculas?' ('Who will receive and honour me, Hypocrisy? No one will, except maybe my Crocodiles and the sly, little foxes'). See also Gnapheus, Hypocrisis (1564), fol. C6 ${ }^{\mathrm{r}}$ (III.1), where Ate muses on her deceit which will ruin Hypocrisy: 'Cum vulpe vulpinari ad hunc decet modum, / Cretesque fas est, mentiendo illudere' ('It is only fitting to catch a fox foxing and to lie to liars').

${ }_{98}$ Gnapheus, Hypocrisis (1564), fol. D5 ${ }^{\mathrm{r}}$ (III.3): 'Videtis, optimi cives, quantis nunc deformata sit / Viciorum monstris Hypocrisis, ut illi larvam hanc detraximus, / Canis hic iacet, hic sus volvitur, hic crocodilus fingit lachrymas. /Ursus, Tygris, Leo, lupus, vipera, Pardalis cor occupant, / Quod-ceu Protheus-in monstrorum bis mille formas vertitur.'
} 
predators represent her cruelty, the dog and pig (and possibly also the spotted panther) her filthiness. ${ }^{99}$ Compare this scene to one of Erasmus's most popular adages, the Silenes of Alcibiades, ${ }^{100}$ but animal allegory is also a recurring motif in the visual propaganda of the Reformation. In particular, the scene calls to mind a woodcut named The Papal Ass: It depicts the Church as a naked woman (symbolizing the whore of Babylon), covered in scales, with an ass's head, an elephant's foot, an ox hoof, and a griffin's claw. ${ }^{101}$ The Pope is also identified with predators like the lion (obviously Pope Leo X in particular), and the clergy with bears, foxes and wolves, who prey on their flock of sheep or geese. ${ }^{102}$ The same identification can already be found in Een troost ende spiegel, where Tobias criticizes the Roman Catholic clergy.

No, they are veritable wolves that Ezekiel speaks of. They drink the milk of their sheep, and they are dressed in their wool, but do not protect them from the wolves. In my opinion, they are nothing but feigning hypocrites and whited sepulchres, who suck dry widows' households and read their long prayers and hours. For this they will be judged severely, I expect; they are false Prophets in sheep's clothing, and inside they are harrowing wolves. ${ }^{103}$

${ }_{99}$ For the panther as symbol for filthiness, see Gnapheus, Morosophus, fol. F1 ${ }^{\mathrm{r}}$ (V.4): 'Cuius tu pallium alioqui candidum facis, / Maculosius sit (proh pudor) vel Pardale' ('whose normally snow-white mantle you tainted (what a shame) like a Panther'). Cf. Dante, Divina commedia, Inferno, 1, 31-33.

${ }_{100}$ Erasmus, Adagia, 2201/II. 3. 1 (Sileni Alcibiadis): 'Denique passim in omni mortalium genere sunt, quorum si formam contemplere corporis, homines et praeclaros homines dicas. Si Silenum explicueris, intus suem aut leonem aut ursum aut asinus invenies' ('Finally there are all sorts of mortals, whom you would easily assume to be men, even distinguished men, judged by their outward appearance. When opening the Silenus figure, inside you will find only pigs, lions, bears or asses'), see ASD II-5, p. 170.216-18.

101 Scribner, For the Sake of Simple Folk, pp. 129-33.

102 Scribner, For the Sake of Simple Folk, pp. 74-132.

${ }^{103}$ Gnapheus, Een troost ende spiegel, fol. A3": 'Neent, het zijn warachtige woluen, daer Ezechiel van spreect, Dat si dat melck eten van haer schapen, ende met die wolle ghecleedt werden mer si en behoedense voor die woluen niet, Ick laet my duncken, dat het zijn beueynsde hypocrijten, ende beschilderde grauen, die wtsuypen der weduwen huysen, ende langhe gebeden oft ghetyden lesen, waer omme si swaerlijcker ordeel ontfangen sullen, dit peynse ic, zijn die valsche Propheten die in schaeps cleederen gaen, ende van binnen zijnt grijpende woluen.' Bibliotheca Reformatoria Neerlandica I, p 155. It goes back to the 'false prophets' in Ezekiel (34:1-10), and combines this biblical passage with the 'hypocritical Pharisees' from St. Matthew's Gospel (23:27 and $7: 15)$. 


\section{Demonization}

Hypocrisy, and initially Psyche as well, are seduced and deceived by two devils, the two Furies from Hades, Ate and Alecto, who pose as 'angels of light', and disguise themselves as mendacious Religiousness and false Doctrine. ${ }^{104}$ Psyche repents and has recourse to the mercy of God. Hypocrisy on the other hand also acknowledges her sins, but she does not repent and even curses the gods, or God. Hypocrisy is then condemned by Jove, or God, and dragged off to hell. In this way Gnapheus shows that the Roman Catholic Church is unknowingly ruled by devils and, as it were, corrupted from the inside out.

In visual reform propaganda, the Roman Catholic Church is often associated with the demonic and with hell; the reform movement, or the Lutheran Church, are, by contrast, associated with Christ and heaven. See, for example, the last two woodcuts of the aforementioned Passional Christi und Antichristi depicting Christ's ascension, whereas the Pope 'is thrust down into hell'. ${ }^{105}$ And a popular woodcut depicting Luther preaching from the pulpit, on his right the Lutheran Church and Christ crucified, ${ }^{106}$ on his left the Pope and clergy in the jaws of hell. ${ }^{107}$ The antithetical visual propaganda of the day may have prompted the play's setting with on the one hand the house of the Litae, on the other Hypocrisy's decorated church, and later the mouth of hell that she enters. The character Hypocrisy, or the Church, is not exactly identified with the Antichrist, as in many anti-Catholic pamphlets and literary works (such as, for instance, Naogeorgus's Lutheran play Pammachius), but she is closely associated with devils and hell: she is seduced by devils, and she eventually descends into hell to be punished.

\section{Conclusion}

Of course Gnapheus did not write and stage a religious play in an entirely Lutheran environment without any consideration for the

\footnotetext{
1042 Corinthians 11, 14: 'et non mirum ipse enim Satanas transfigurat se in angelum lucis', 'And no marvel, for Satan himself is transformed into an angel of light'. Translation KJV.

${ }^{105}$ Scribner, For the Sake of Simple Folk, pp. 154-55.

106 The humble dwelling of the Litae that Psyche visits was also identified by a cross.

${ }^{107}$ Scribner, For the Sake of Simple Folk, p. 206.
} 
convictions of his public, even though at first sight this may seem to be the case, because he was excommunicated from the Lutheran Church partly on account of his Hypocrisis, written and performed in Lutheran Königsberg. However, Gnapheus wrote an elaborate apology in which he refutes all accusations, and in abbreviated form he does roughly the same thing in the dedicatory epistle to the reprint of the play. This (admittedly thoroughly revised) version of Hypocrisis was published in Luther's own city of Wittenberg, probably with the intention of clearing the author's name, but also of discrediting his prosecutor Staphylus, who had by that time abandoned the Lutheran Church in favour of Catholicism.

Hypocrisis is a satirical attack on the Roman Catholic Church. The play emphasizes the pomp and circumstance of the Church, and Catholic practices and customs, all lumped together and embodied in the personified abstraction Hypocrisy. Hypocrisy is easily identifiable as the Church through textual references, as well as by means of costumes and stage action. Gnapheus lets Hypocrisy fail in defending Psyche (the personification of the human soul) before Jove, and in so doing he denies that the Roman Catholic Church mediates between God and man. He even allows Hypocrisy to be condemned and to descend into hell, which makes a visually persuasive argument against the Church. The fact that Hypocrisy represents Catholicism is made clearer, and cast in an unfavourable light, through her identification with the Pharisees (commonly bracketed together with the clergy), beasts of prey and devils.

Gnapheus contrasts the Church (overdressed Hypocrisy, and her adorned temple) with its exact opposite of an evangelical belief (Repentance and the Litae, or Christ, and their respective humble dwellings). Hypocrisis is thus also a dramatized Lutheran catechism. After the Roman Catholic Church has served its turn (after Hypocrisy's demise and descent into hell), the journey continues. During Psyche's allegorical pilgrimage from sin to salvation, Gnapheus dramatizes certain Lutheran tenets, such as the dogma on the Law and Gospel. In so doing Gnapheus teaches Lutheran doctrine, and strengthens his public in their new beliefs, although the theologian Staphylus held different opinions.

Just like classical drama, Gnapheus's Hypocrisis is written in Latin and divided into five acts, but that is where the similarities end. Hypocrisis is heavily indebted to the vernacular morality play. The vernacular morality plays may have appealed to Gnapheus because of their didac- 
tic and moralistic function, and suitability for satire. Above all, the play is strongly embedded in the polemical discourse of the Reformation; through his sophisticated use of various familiar and traditional motifs and modes of representation for the depiction of the Roman Catholic Church, Gnapheus fully combines aesthetics and didactics with his ardent views on reform. 